\title{
BIOCHEMICAL ROLE OF XANTHINE OXIDOREDUCTASE AND ITS NATURAL INHIBITORS: AN OVERVIEW
}

\author{
UMA RAJESWARI BATCHU, KIRANMAI MANDAVA \\ Department of Pharmaceutical Chemistry, Bharat Institute of Technology, India \\ Email: gchaitra.kiran@gmail.com
}

Received: 06 Jul 2016 Revised and Accepted: 12 Aug 2016

\begin{abstract}
Xanthine oxidoreductase (XOR) is a widely distributed housekeeping enzyme in mammals that catalyzes the last two steps in human purine catabolism to produce uric acid. The enzyme exists as a homodimer with independent electron transfer in each monomer. This has been studied extensively as a major constituent of the milk fat globule membrane (MFGM) which surrounds fat globules in cow's milk even though purine catabolism is the most accepted function of XOR. A huge number of literature highlights on the different catalytic forms of XOR and their importance in the generation of reactive oxygen species/reactive nitrogen species (ROS/RNS) and synthesis of uric acid which are involved in many physiological and pathological processes. However, a slight ambiguity resides in their biochemical functions. The aim of this article was to review the literature published on the structural, catalytical, physiological and pathological role of XOR and to resolve the ambiguity in biochemical processes and to firm up various natural inhibitors of XOR collectively. Uric acid, the product of purine catabolism shows antioxidant activity, and XOR-derived ROS and RNS play a role in innate immunity, milk secretion and also be involved in signaling and metabolism of xenobiotics. Furthermore, XOR is likely to be engaged in pathology because of excessive production of uric acid and ROS/RNS. This review also reports natural XOR inhibitors in plants which inhibit the enzyme to treat XOR associated pathology.
\end{abstract}

Keywords: Xanthine oxidoreductase, Housekeeping enzyme, Purine catabolism, Hyperuricemia, Allopurinol, XOR natural inhibitors

(C) 2016 The Authors. Published by Innovare Academic Sciences Pvt Ltd. This is an open access article under the CC BY license (http://creativecommons. org/licenses/by/4. 0/) DOI: http://dx.doi.org/10.22159/ijpps.v8i10.13927

\section{INTRODUCTION}

Xanthine oxidoreductase (XOR) is a widely distributed enzyme which has been extensively studied for more than $100 \mathrm{y}$ because of its abundance in bovine milk which is available on a large scale. Bovine milk XOR is the first studied enzyme [1]. XOR has been isolated from different species from bacteria to men, yet minor structural and catalytical differences found in different species [2-5]. $\mathrm{XOR}$ is a truly representative form of two enzymes i. e xanthine dehydrogenase (XDH; EC 1.1.1.204) and xanthine oxidase (XO; EC 1.1.3.22). They represent two forms of the same gene product. Mammalian XOR is synthesized in XDH form but converted to XO through irreversible post-translational modification in the presence of various stimuli [3, 6-8]. Merely mammalian XOR exists as two forms, whereas other species contains only the XDH form.

This property is an added advantage to mammals to study XOR as an evolutionarily conserved housekeeping enzyme [6]. It is a wellstudied enzyme with a huge number of biochemical functions which plays a major role in physiology and pathology of humans. However, many review papers have been published on structural, physiology, pathological, and catalytic mechanisms of this enzyme, several questions yet to be answered to resolve ambiguity in the interconversion of $\mathrm{XDH}$ to $\mathrm{XO}$ and its influence on biochemical activities. Present review mainly focused on resolving ambiguity with respect to interconversions and their influence on principal biochemical activities and also outlined the natural inhibitors of these enzymes.

\section{Molecular structure and pathway of electron transfer in XOR}

XOR is a molybdenum-containing enzyme belongs to XO family. All the enzymes of this family possess multiple iron-sulfur clusters (at least two) in addition to the molybdenum center and FAD. Mammalian XOR is a homodimer consisting of two independent subunits with a molecular mass of 145KDa [6, 9-11]. Each subunit consists of one molybdopterin (MO-pterin) unit, two un-identical non-sulphur redox centers $(\mathrm{Fe} / \mathrm{SI}$ and $\mathrm{Fe} / \mathrm{SII})$ and $\mathrm{FAD}$ as cofactor distributed in the C-terminal (85 KDa), N-terminal $(20 \mathrm{KDa})$ and intermediate (40 KDa) domains respectively [9, 12-13]. Members of the XO family of enzymes usually catalyzes the oxidative hydroxylation of carbon center of their substrates typically aromatic heterocyclic's or aldehydes. In this mechanism Mo (VI) is reduced to Mo (IV) at the active site [2]. This follows the oxidation of fully reduced XOR molecule includes the transfer of its six electrons to acceptor $[14,15]$. Usually the substrate binds to the active site positioned nearer to molybdenum domain from there electrons transfers to acceptor through iron-sulfur proteins and flavin adenine dinucleotide (FAD) respectively [16]. Electron transfer is independent in two independent subunits [2].

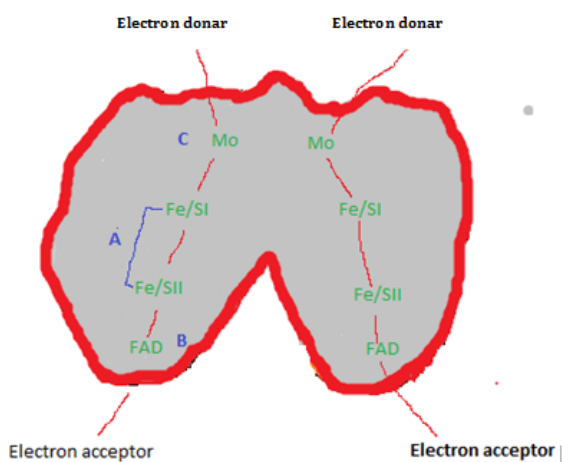

Fig. 1: Inverted butterfly catalytic structure and electron transfer pathway of XOR dimer: Each XOR monomer includes A. $\mathrm{N}$-terminal domain (20-kDa) B. Intermediate domain (40-kDa) C. C-terminal domain (85-kDa). The pathway of electron flow in XOR includes an MO-pterin unit, two unequal iron-sulfur redox centers Fe2/S2I and Fe2/S2II) and one molecule of FAD respectively [reviewed in 2,14$]$

In the fig. [1] Electron donors are of same substrates, but electron acceptor is different in two forms of the enzyme. In $\mathrm{XDH}$ nicotinamide adenine dinucleotide $\left(\mathrm{NAD}^{+}\right)$is the preferred acceptor and in case of $\mathrm{XO}$ form oxygen $\left(\mathrm{O}_{2}\right)$ is the electron acceptor which 
can produce superoxide anion, hydrogen peroxide $\left(\mathrm{H}_{2} \mathrm{O}_{2}\right)$ which acts as an important signaling molecule and also has a potential to generate reactive oxygen species (ROS) but in intermediate form XOD which was produced because of reversible thiol oxidation of $\mathrm{XDH}$ can reduce both $\mathrm{NAD}^{+}$and $\mathrm{O}_{2}[15,17-18]$. The intermediate form can also produce ROS because of $\mathrm{O}_{2}$ reduction.

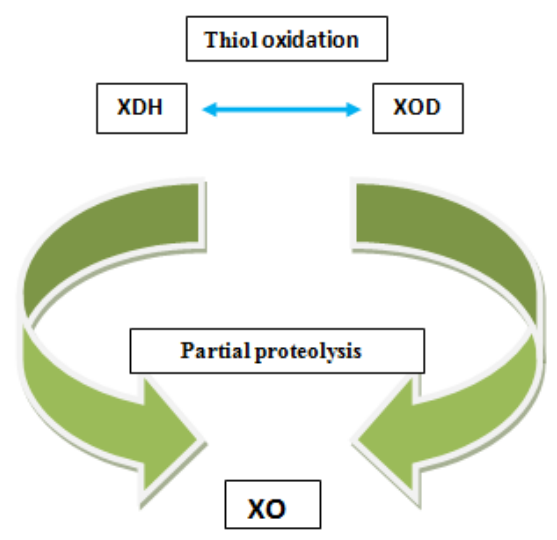

Fig. 2: Biological interconversions of mammalian XOR: Thiol oxidation converts XDH into reversible XOD (intermediate form) of the enzyme. Partial proteolysis converts XDH and XOD into the irreversible XO form [reviewed in 15, 17-18]

Recently NADH oxidase activity of an enzyme has been identified where NADH donates its electrons directly to FAD to an electron acceptor $\mathrm{O}_{2}$ [19]. And also some papers have reviewed nitrates reducing power of XOR especially XO form. XO can reduce inorganic nitrates, glyceryl nitrates to nitric oxide (NO) under hypoxic conditions in the presence of NADH or xanthine as a reducing substrate which acts as an important signaling molecule. Moreover, in the presence of $\mathrm{O}_{2}$, superoxide reacts rapidly with $\mathrm{NO}$ to generate reactive nitrogen species (RNS) particularly peroxynitrite an even more powerful bactericidal agent [17, 20-21]. A further complication is that this reaction can affect vasodilation effect of NO particularly in the ischemic conditions of vasculature when NO synthase activity is low. In this context, the two enzymes can be seen as complementary [22].

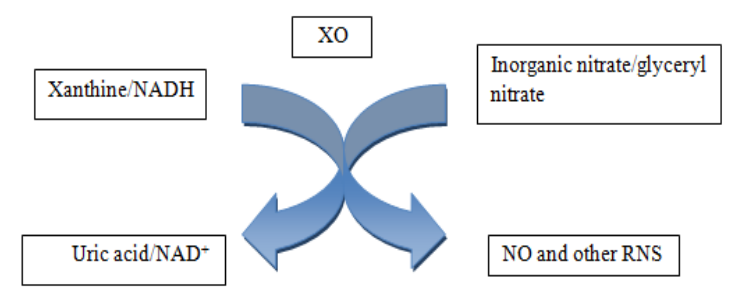

Fig. 3: Reduction mechanism of nitrates by XO: Xanthine/NADH donates electrons to nitrates and oxidizes to uric acid/NAD ${ }^{+}$. Nitrates accept the electrons and reduces to NO and other RNS

\section{Distribution of mammalian XOR}

In mammals, XOR has been distributed in many organs; however highest levels are found in the liver, intestine and biological fluids such as blood, milk [23-26]. In respect of humans, highest levels are found in liver, intestine [27-31] while a very low activity has been detected in other organs [32-33]. Interestingly, human endothelial cells from the microvasculature of several tissues have been reported as expressing high levels of XOR activity [34]. XOR can be found in human milk and blood, but activity is low compared to bovine milk and blood under physiological conditions, but it can be increased under pathological conditions. [5, 35-37].

\section{Biochemical roles of XOR}

Being a widely distributed enzyme XOR has been involved in many biochemical functions. These functions play a major ole in physiology and pathology.

\section{Physiological role of XOR}

The physiological involvement of XOR is potentially complex. Although normal cellular/tissue distributed enzyme has an affinity for several substrates including aldehydes, purines, pyrimidines, pteridines, aza purines, heterocyclic compounds and retinol $[35,38]$ but the conventional role is purine catabolism especially in the liver $[9,15]$. Despite purine catabolism other housekeeping functions of XOR are detoxification of xenobiotics, including antiviral and anticancer agents and regulation of cellular redox potential, lactation $[6,39,40]$. First three reactions involve in the generation of ROS/RNS, which are crucial to physiological functions such as innate immune defense and signal transduction.

\section{Purine catabolism}

In normal physiological conditions, XDH form of the enzyme was predominant in tissues and catalyzing the oxidative hydroxylation of hypoxanthine to xanthine and the oxidation of xanthine to uric acid. Uric acid acts as a potent antioxidant and free radical scavenger necessary to protect a cell from oxidative damage caused by ROS and RNS $[9,15,19,41]$. This has been the proposed reason for increased lifespan in humans. Therefore, the lack of uricase activity could represent an evolutionary advantage for uricotelic primates over ureotelic mammals [42-43].

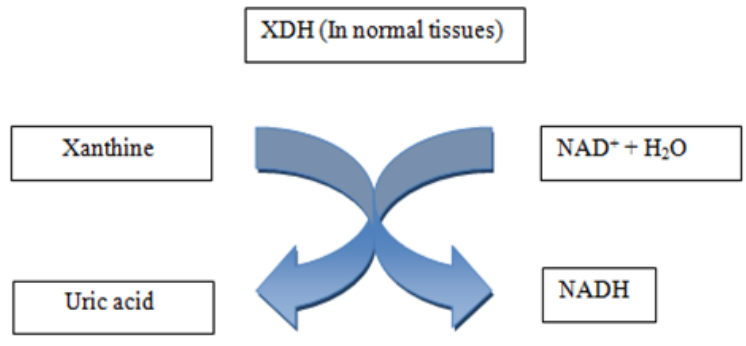

Fig. 4: Mechanism of action of XDH: Xanthine donates electrons to $\mathrm{NAD}^{+}$and oxidizes to uric acid. $\mathrm{NAD}^{+}$accepts the electrons and is reduced to NADH in normal tissues

Purine catabolism has also been detected in epithelial cells and vascular endothelial cells, but uric acid is secreted on the surface of these cells expanding their role extra in nasal fluid, saliva, and other body fluids as a systemic antioxidant [44-47].

\section{Innate immune defense}

Surprisingly XOR itself contributes the synthesis of numerous ROS and RNS in XO form. In the early 1980s hypothesized that XDH can be converted to $\mathrm{XO}$ in the presence of stimuli (cell and tissue injury). This property of XOR to rapidly convert from XDH to XO makes XOR an ideal component for a fast immune response $[6,48]$.

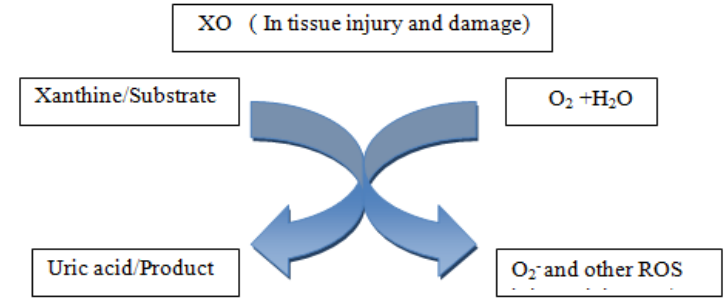

Fig. 5: Mechanism of action of XO: Xanthine/other substrate donates electrons to $\mathrm{O}_{2}$ and oxidizes to uric acid/other substrates.

$\mathrm{O}_{2}$ accepts the electrons and reduces to $\mathrm{O}_{2}$-and other ROS 
From last two decades, attention has been focused on the ability of the XOR to generate ROS/RNS. At lower levels these two acts as secondary messengers, but at higher levels, they have an antimicrobial action which plays a major role in the cellular innate immune activity [49-51]. In addition to ROS/RNS uric acid the product of purine catabolism also plays a major role in immune defense mechanism as an antioxidant and free radical scavenger, besides being an anti-inflammatory effector with numerous protective roles in the body. The protective functions are not only at the cellular level but also involved in systemic functions due to circulating XOR and serum uric acid [47, 52-53]. Circulating XOR is in XO form due to proteolysis by plasma proteases [54]. Healthy mammals have low levels of circulating XOR. In the case of humans, these levels can dramatically increase in response to a range of diseases, particularly those affecting the liver [18]. XOR has been implicated as a destructive agent, particularly in many forms of ischemic-reperfusion (IR) injury due to the production of ROS/RNS $[6,16,41,55]$. Nevertheless, the cytotoxic properties of ROS/RNS can also be beneficial, and an antimicrobial role for bovine milk XOR has been considered for many years. XOR initiates an antimicrobial response in response to infection, cytokines or other proinflammatory mediators. These stimulate XDH to XO conversion which leads to the generation of ROS, and neutrophil infiltration inflammatory response. The neutrophils then act to combat the infectious agents [56-58]. Further examples of antimicrobial action of XOR identified in GIT, bile duct, vascular endothelium resulting from the generation of ROS and RNS. XOR also plays a major antimicrobial role in the bile juice produced from the lining of bile ducts $[6,40]$.

Recently new hypothesis were proposed to explain the antimicrobial property of milk. The location of XOR on the surface of fat globules in milk is well suited to its proposed antimicrobial role of mammalian milk. It is still an area of research how the purely structural role of XOR in secretion relates to the proposed antimicrobial function. It is most likely to be hypothesized that the pathogenic bacteria which can be targeted epithelial membrane antigens of the digestive tract are likely to bind to similar antigens on MFGM [59]. This interaction probably brought into close contact with XOR which is present on MFGM reinforced by the enzyme affinity for acidic polysaccharides, present on many bacterial capsules [60]. This interaction could be the stimulus for conversion of XDH to XO to generate ROS [61]. Still, it is not clear which is reducing substrate for the $\mathrm{XO}$. This aspect is being under active area of investigation. XOR derived $\mathrm{H}_{2} \mathrm{O}_{2}$ exerts its antimicrobial effects by acting as a substrate for the lactoperoxidase system in milk.

Unknown substrate $+\mathrm{O}_{2}+\mathrm{H}_{2} \mathrm{O} \rightarrow$ Unknown product $+\mathrm{O}_{2}$-and other ROS

In view of the newly discovered role of XOR to reduce nitrite to NO in the generation of RNS particularly peroxynitrite, can be seen as a potential mechanism of antimicrobial activity of milk. Usually, nitrate concentrations are likely to be high in the immediate micro-environment of enteric bacteria favoring XOR-catalyzed reduction to NO.

\section{Signal transduction}

As discussed above in innate immune defense at low levels XORgenerated ROS/RNS act as secondary messengers in signal transduction, but convincing proof of the involvement in cellular signaling yet to be ambiguous. Recently a new hypothesis described the location of XOR on the outer surface of cultured human endothelial and epithelial cells, and to be localized to surfaces opposed to those of closely neighboring cells which are involved in cell-cell interactions [62].

In addition to above prominent activities, an XOR-generated ROS are responsible for Iron mobilization from ferritin in the liver [63], iron absorption in the intestinal mucosal [64] and the induction of proliferation [65-67]. It was also postulated that free radical generation by XOR and various metabolic pathways in developmental animals believed to be influenced the development [3].

\section{Role of XOR in lactation}

Recently, evidence has been reported for the involvement of XOR in milk secretion [68]. XOR occurs in the milk fat globule membrane (MFGM). Fat droplets originate in the endoplasmic reticulum of the mammary secretory cell. In the secretion process, they migrate to the luminal surface and bud off from the cell, enveloped by the apical cell membrane to form a MFGM $[61,69]$. Immediately after leaving the cell, the fat droplet is surrounded by a true biological membrane. During this process, the enzyme moves from the cytoplasm of the secretory cell to the apical cell membrane where it combines with adipophilin and butyrophilin. XDH was shown to form a complex with these proteins which mediate coupling between lipid droplet and the apical plasma membrane in the secretion process. This activity depends only on its protein structure not owing to catalytic activity.

Regardless of many decades of research into XOR, the human enzyme has characterized recently. The catalytic activity of human liver XOR is similar to bovine milk [70] enzyme, but surprisingly human milk enzyme has low xanthine oxidase activity due to its low molybdenum content (less than 5\%). The NADH oxidase activity of human milk XOR is essentially same as that of the bovine milk enzyme which involves only FAD site [71]. The low enzymatic activity of human XOR is a puzzle [72]. If the process of milk secretion does not require enzymatic activity, this is only necessary in the first few weeks postpartum, in order to fulfill an antimicrobial role in the neonatal gut. Thereafter, this requirement ceases, and the activity falls to the level commonly found in purified milk XOR, which is generally obtained several weeks after birth. It was also reported that goat and sheep milk enzymes have relatively low activity similar to human XOR which has molybdenum contents of $9 \%$ and $18 \%$ respectively.

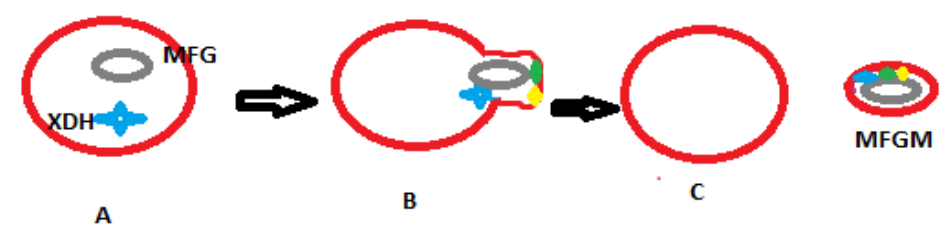

Fig. 6: Structural role of XOR in milk secretion process of mammary secretory cell

A. Fat droplets originate in the endoplasmic reticulum of the mammary secretory cell and XOR movement from the cytoplasm of the secretory cell to the apical cell membrane B. Migration of fat droplets to the luminal surface enveloped by the apical cell membrane to form a MFGM [61,69] and combining of XOR with adipophilin and butyrophilin on apical cell membrane C. XDH mediates coupling between lipid droplet and the apical plasma membrane in the secretion process.

\section{Pathological role of XOR}

So far several hundreds of publications have published about the involvement of XOR in pathogenesis, although the specific pathogenic mechanisms are still debated [41]. Whatever may be the mechanisms the agents involved in pathogenesis are ROS/RNS and uric acid generated by XOR.

\section{Role of ROS/RNS in pathology}

The usual function of ROS/RNS as a destructive agent has been illustrated in 1986 in IR injury [73]. IR injury is cell death that commonly results from interruption of blood flow to specific tissue, which occurs in a myocardial infarction or stroke. It can represent an unusual response to sequence a normal physiological process in 
the vasculature, namely inflammation. On the basis of their studies of feline intestinal ischemia, Granger and colleagues proposed the consequences of events. In the course of ischemia, the energy status of the cell falls, transmembrane ion gradients break down, and the levels of intracellular calcium increase, which leads to activation of a calcium-dependent protease that irreversibly converts XDH into the XO. Concomitantly, cellular ATP is catabolized to hypoxanthine, which accumulates. On reperfusion, oxygen again becomes available and is reduced by the hypoxanthine-XO system, generating superoxide and $\mathrm{H}_{2} \mathrm{O}_{2}$. These ROS then interact to generate hydroxyl radicals with consequent oxidation of biological molecules, including proteins, lipids, and nucleic acids. This process directs to tissue injury which plays a major role in respiratory and cardiovascular disease. This mechanism also has been considered to be a reason for the difficulty in organ preservation for transplantation, particularly for XOR-rich organs, such as the intestine and liver. Therefore, the University of Wisconsin preservation solution includes allopurinol although XOR activity was not definitively shown to be the main source of oxidative stress in tissue grafting [74].

As well as in vascular pathology, the exocytosis of XOR upon cellular insults/stress, such as ischemia has been recognized to be a component in the pathogenesis of reperfusion injury [75-76]. In addition, several studies have suggested that circulating XOR can bind to vascular endothelial cells, thus providing a center of attention for oxidative stress/damage at sites far from the initial injury $[75,77]$.

During the 1970s and early 1980s, a new hypothesis was promoted to explore an association between cows' milk XOR and ischemic heart disease $[78,79]$. In this context, produced anti-bovine MFGM antibodies might cross-react with platelet membrane antigens, inducing platelet aggregation and hence atherogenesis. However, this hypothesis was later disproved, and it can be argued that they were anti-XOR autoantibodies and their role is protective, serving to remove endogenous XOR arising from various pathological states. Their elevated levels in myocardial infarction (MI) patients could be in response to enzyme released from vascular endothelial cell lesions [79].

\section{Role of uric acid in pathology}

Hyperuricemia is the most cited pathology caused by XOR. It is a pathological condition caused by several reasons including over production by XOR, underexcretion, renal tubular disorders of uric acid. A hyperuricemic state possibly will also develop following tumor cell necrosis producing the so-called "tumor lysis syndrome" as neoplastic cells leak purines into the interstitial fluid and plasma, potentially leading to renal failure [80-81]. Congenital diseases may also give rise to hyperuricemia; the two most common are LeschNyhan and Kelley-Seegmiller Syndromes-X-linked recessive disorders involving the overproduction of uric acid owing to complete or partial lack of hypoxanthine guanine phosphoribosyl transferase (HGPRT) in elevated concentrations of XOR substrates in the cell [80, 82-83]. Hyperuricemia condition follows various pathological changes. Even though most frequently expressed clinical condition was gout with the deposition of uric acid crystals, particularly in the joints, giving rise to rheumatic problems such as dysarthria it may develop other insignificant pathologies such as urolithiasis/nephrolithiasis, chronic kidney diseases, and cardiac disorders also [84-85].

So far discussion carried about XOR physiological activities, its association in pathology. In addition to this, deficiency of xanthine oxidase due to a genetic defect or severe liver deficiency has been detected. Hypouricemia, increased excretion of hypoxanthine and xanthine are associated with xanthine oxidase deficiency [86].

\section{Inhibition of XOR}

The most commonly prescribed drugs for hyperuricemia of any cause is allopurinol, which has been a central part of clinical therapeutics for over $60 \mathrm{y}$. Allopurinol is converted to oxypurinol (also xanthine) in the process of inhibiting XOR, and is a competitive inhibitor of xanthine that actually inactivates the enzyme. It remains the only commercially available inhibitor of XOR in the United States [87]. Many recent studies have focused on natural and synthetic inhibitors of XOR that might be used as part of a daily regimen or be used to replace or synergize with allopurinol because of severe side effects of allopurinol [87-89]. Possibly the most promising synthetic pharmaceutical is known as TEI-6720 or Febuxostat [87, 90-92]. This compound is not a competitive inhibitor of XOR but instead interfere at the active site as a stably bound/docked molecule. It was proposed to be safe in patients with renal failure, but the evidence is not yet available [93-94].

In spite of the wide use of synthetic analogs in the treatment of gout the search for novel XO inhibitors with fewer side effects and potent activity are essential not only for the treatment of gout but also treat other diseases associated with the $\mathrm{XO}$ activity. In this review, we tabulated the various natural XO inhibitors that have been identified.

Table 1: List of natural XO inhibitors and $\mathrm{IC}_{50}$ values

\begin{tabular}{|c|c|c|c|c|}
\hline Plant name & Part/extract & Active phyto constituent & $\begin{array}{l}\text { IC }{ }_{50} \text { value of } \mu \mathrm{g} / \mathrm{ml} \text { or) } \\
\mu \mathrm{m} / \mathrm{ml}\end{array}$ & Reference \\
\hline Silybum marianum & Sylimarin extract & Silibinin & $27.58+/-3.48$ & [95] \\
\hline Tephrosia purpurea & Methanolic root extract & Polyphenols, Flavonoids & - & [96] \\
\hline Erythrina indica & Methanolic stem bark extract & Flavonoids & 52.75 & [97] \\
\hline Erythrina stricta & Chloroform fraction & - & 21.2 & [99] \\
\hline Cranberry & Juice & - & 2.4 & [99] \\
\hline Purple grapes & Juice & - & 3.5 & [99] \\
\hline Black tea & Extract & & 5.8 & [99] \\
\hline Green tea & Dried leaves & Epigallocatechin gallate (EGCG) & 0.48 & [100] \\
\hline Japanese knotweed & Root & Resveratrol & - & {$[100]$} \\
\hline Origanum syriacum & Aqueous extract of aerial parts & - & 317 & [101] \\
\hline Origanum vulgare $L$ & Aqueous extract of aerial parts & - & 403.9 & [101] \\
\hline Hyoscyamus reticulatus & Aqueous extract of aerial parts & - & 12.8 & [101] \\
\hline Achillea fragrantissima & Aqueous extract of Aerial parts & - & 179.9 & [101] \\
\hline Daphne linearifolia & Aqueous extract of aerial parts & - & - & [101] \\
\hline Hibiscus sabdariffa & Aqueous extract of calyx & - & - & [101] \\
\hline Aristolochia maurorum & Aqueous extract of aerial parts & - & - & [101] \\
\hline Citrullus colocynthis & Aqueous extract of seed & - & - & [101] \\
\hline Laurus nobilis & Aqueous extract of leaves & - & - & [101] \\
\hline Pimpinella anisum & Aqueous extract of fruit & - & 300.4 & [101] \\
\hline Tecoma stans & Ethanol extract & - & 38.97 & [102] \\
\hline Cassia fistula & Methanol seeds extract & Flavonoids & 11.07 & [103] \\
\hline Conyza bonariensis & Methanol extracts & $\begin{array}{l}\text { Syringic acid Takakin 8-0- } \\
\text { glucuronide }\end{array}$ & $\begin{array}{l}500+/-41 \\
170+/-12\end{array}$ & [104] \\
\hline Koelreuteria henryi & Acetone extracts & - & $91.8 \pm 1.7$ & [105] \\
\hline
\end{tabular}




\begin{tabular}{|c|c|c|c|c|}
\hline Prunus campanulata & Acetone extracts & - & $64.6 \pm 5.8$ & {$[105]$} \\
\hline Rhodiola rosea & Acetone extracts & - & $56.00 \pm 1.0$ & [105] \\
\hline Aronia melanocarpa & Berries,bark extract & Anthocyanins & - & [106] \\
\hline Oroxylum indicum & Seed extract & $\begin{array}{l}\text { Oroxin } \mathrm{B} \text {, oroxinA, baicalin, } \\
\text { baicalein }\end{array}$ & - & [107] \\
\hline Scutellaria baicalensis & Root & $\begin{array}{l}\text { Baicalin, wogonin, } \\
\text { baicalein }\end{array}$ & - & [108] \\
\hline Cinnamomum cassia & Methanol extract of twig & - & 18 & [109] \\
\hline $\begin{array}{l}\text { Chrysanthemum } \\
\text { indicum }\end{array}$ & Methanol extract of flower & - & 22 & [109] \\
\hline Lycopus europaeus & Methanol extract of leaves & - & 26 & [109] \\
\hline Polygonum cuspidatum & Water extracts of rhizome & - & 38 & [109] \\
\hline $\begin{array}{l}\text { Semecarpus } \\
\text { Anacardium }\end{array}$ & Ethyl acetate fraction of seeds & Tetrahydroxymentoflavone & 92 & [110] \\
\hline Lagerstroemia speciosa & Aqueous extracts of leaves & Valoniec acid and ellagic acid & - & [111] \\
\hline Cyathea spinulosa & Tree & Caffeic acid & - & [112] \\
\hline Salvia mitiorrhiza & Roots & Lithospermic acid & - & [113] \\
\hline Palhinhaea cernua & Ethanolic extract of club moss & $\begin{array}{l}\text { 1-apigenin-4-(2-o-p-coumaroyl) } \beta \text { - } \\
\text { d-glucopyranoside }\end{array}$ & $23.95 \pm 0.43$ & [114] \\
\hline $\begin{array}{l}\text { Cinnamomum } \\
\text { osmophloeum }\end{array}$ & Essential oil from leaves & Cinnamaldehyde & 16.3 & [115] \\
\hline Momdica charantia & Aqueous extract & coumarin & - & [116] \\
\hline Vicia faba & Plant extracts & Polyphenolic compounds & $40-135$ & [117] \\
\hline Lotus edulis & Plant extracts & Polyphenolic compounds & $55-260$ & [117] \\
\hline Chrysanthemum sinense & Methanolic extracts of flowers & $\begin{array}{l}\text { Acaacetin } 7-0-(3-0 \text {-acetyl) } \beta-d- \\
\text { glucopyranoside }\end{array}$ & $0.13-2.31$ & [118] \\
\hline Caulerpa species & Seaweed & Caulerpenyne & - & [119] \\
\hline $\begin{array}{l}\text { Lonicera hypo-glauca } \\
\text { (lh) }\end{array}$ & Ethanolic extract & Bioflavonoid and lonicera flavone & 35.2 & [120] \\
\hline Teucrium polium & $\begin{array}{l}\text { Methanol, chloroform, ethyl } \\
\text { acetate extracts }\end{array}$ & $\begin{array}{l}\text { Proanthocyanidins, gallic } \\
\text { acid,catechin and epicatechin }\end{array}$ & $0.07-11.76$ & [121] \\
\hline Tephrosia purpurea & Root extracts & Polyphenols and flavonoids & - & [122] \\
\hline $\begin{array}{l}\text { Chrysanthemum } \\
\text { coronarium }\end{array}$ & Methanol extract & - & 199.5 & [123] \\
\hline Achillea biebersteinii & Methanol extract & - & 360.0 & [123] \\
\hline Rosmarinus officinalis & Methanol extract & - & 650.0 & [123] \\
\hline Ginkgo biloba & Methanol extract & - & 595.8 & [123] \\
\hline $\begin{array}{l}\text { Helianthemum } \\
\text { ledifolium }\end{array}$ & Methanol extract & - & - & [123] \\
\hline Majorana syriaca & Methanol extract & - & - & [123] \\
\hline Mentha spicata & Methanol extract & - & - & [123] \\
\hline Populus nigra & $\begin{array}{l}\text { Methylene chloride-methanolic } \\
\text { extracts }\end{array}$ & - & 8.3 & [124] \\
\hline Betula pendula & $\begin{array}{l}\text { Methylene chloride-methanolic } \\
\text { extracts }\end{array}$ & - & 25.9 & [124] \\
\hline $\begin{array}{l}\text { caryophyllus } \\
\text { aromaticus }\end{array}$ & Ethanolic extract & - & 5 & [124] \\
\hline Hypericum perforatum & Ethanolic extract & - & 50 & [124] \\
\hline Fistulina hepatica & Methanol extract & - & - & [125] \\
\hline Hypholoma fasciculare & Methanol extract & - & - & [125] \\
\hline $\begin{array}{l}\text { Infundibulicy } \\
\text { begeotropa }\end{array}$ & Methanol extract & - & - & [125] \\
\hline Tricholoma populinum & Methanol extract & - & - & [125] \\
\hline Eucalyptus deglupta & - & - & 44.5 & [126] \\
\hline Syzgiumma lacense & - & - & 51 & [126] \\
\hline Olive & Leaf extract & $\begin{array}{l}\text { Secoiridoidoleuropein and other } \\
\text { apigenin derivative }\end{array}$ & 53.0 & [127] \\
\hline Cinnamomum cassia & Methanol extract of the twig & - & 18 & [128] \\
\hline Polygonum cuspidatum & Rhizome extract & - & 38 & [128] \\
\hline
\end{tabular}

XO-Xanthine oxidase

All natural inhibitors extracted from specific plants collectively belongs to large groups of chemical constituents includes flavonoids, terpenoids, essential oils, polyphenols, glycosides anthocyanins and others. In addition to these plants, majorities of medicinal plants were previously reviewed [8, 129-132].

\section{CONCLUSION}

The capability of the multifunctional enzyme XOR to execute various biochemical reactions owing to the synthesis of antioxidant uric acid and generation of ROS/RNS makes it an outstanding intra and extracellular protective housekeeping enzyme and an important component of the innate immune system. XOR is involved in numerous features of mammalian innate immunity such as antimicrobial activity in various regions due to the generation of ROS/RNS and also play a major role in the oxidative defense because of the synthesis of uric acid by purine catabolism. Apart from defense, an XOR-derived ROS/RNS have multiple potential roles, in both intra-and extracellular signaling.

Additionally, the role of the enzyme in the process of milk secretion has long been suspected and recently convincingly demonstrated. 
The structural role of XOR protein, rather than an enzymatic activity in milk secretion is unexpected.

XOR is also involved in pathology due to the generation of ROS/RNS and synthesis of uric acid. Moreover, ROS and RNS have the capacity to combat infection and to promulgate injury throughout the vascular system. Similarly uric acid has the capacity to act as an antioxidant and at high concentrations able to cause hyperuricemia. For these reasons the levels of the enzyme are subject to rigorous control by the associated autoantibodies, a rare example of beneficial autoimmunity.

Finally, the disease burden of hyperuricemia, which majorly involves in gout remains a major problem and increasing day by day. The available synthetic XO inhibitors are typically used to treat gout or to reduce serum levels of uric acid, yet they are exhibiting a huge number of side effects. Hence the research has been focused on natural XO inhibitors, which could have therapeutic potential in selected groups of patients with gout. However, much of the information concerning structure, catalytic mechanism and biochemical functions and also various natural inhibitors cited in this review is truthful.

\section{ACKNOWLEDGEMENT}

Authors are thankful to Sri C. Venugopal Reddy, Secretary, Bharat Institutions for his constant encouragement towards research.

\section{CONFLICT OF INTEREST}

Self-financed. No conflict of interest

\section{REFERENCES}

1. Linder N, Rapola J, Raivio KO. Cellular expression of xanthine oxidoreductase protein in normal human tissues. Lab Invest 1999;79:967-74.

2. Rouault, Tracey. Molybdenum-containing iron-sulphur enzymes. Iron-Sulfur Clusters in Chemistry and Biology. USA: Maryland; 2014.

3. Eger BT, Okamoto K, Enroth C, Sato M, Nishino T, Pai EF, Nishino T. Purification, crystallization and preliminary Xray diffraction studies of xanthine dehydrogenase and xanthine oxidase isolated from bovine milk. ActaCrystallogr Sect D: Biol Crystallogr 2000;56:1656-8.

4. Oxidative stress by Drbry and Mckersie university of Guelph. Available from: http://wwwplantstresscom/articles/ oxidative \%20stresshtm/1996. [Last accessed on 02 Jun 2016].

5. Parks DA, Granger DN. Xanthine oxidase: biochemistry, distribution, and physiology. Acta Physiol Scand Suppl 1986;548:87-99.

6. Claudia Vorbach, Roger Harrison, Mario R Capecchi. Xanthine oxidoreductase is central to the evolution and function of the innate immune system. Trends Immunol 2003;24:9.

7. Allen RG, Balon AK. Oxidative influence in development and differentiation: an overview of a free radical theory of development. Free Radical Biol Med 1989;6:631-61.

8. Shalini Kapoor Mehta, Naira Nayeem. Natural xanthine oxidase inhibitors for management of gout: a review. J Med Health Sci 2014;3:4-13.

9. Bray RC. Molybdenum iron-sulfur flavin hydroxylases and related enzymes. Enzym 1975;12:299-419.

10. Hille R. The mononuclear molybdenum enzymes. Chem Rev 1996:96:2757-816.

11. James M Pauff, Jinjin Zhang, Charles E Bell, Russ Hille. Substrate orientation in xanthine oxidase: crystal structure of the enzyme in reaction with 2-hydroxy-6-methylpurine. J Biol Chem 2008;283:4818-24.

12. Ichida K. Identification of two mutations in human xanthine dehydrogenase genes responsible for classical type I xanthinuria. J Clin Invest 1997;99:2391-7.

13. Garattini E. Mammalian molybdo-flavoenzymes, an expanding family of proteins: structure, genetics, regulation, function, and pathophysiology. Biochem J 2003;372:15-32.

14. Nishino T, Okamoto K, Eger BT, Pai EF. Mammalian xanthine oxidoreductase-mechanism of transition from xanthine dehydrogenase to xanthine oxidase. FEBS J 2008;275:3278-89.
15. Hille R, Nishino T. Flavoprotein structure and mechanism of Xanthine oxidase and Xanthine dehydrogenase. FASEB J 1995;9:995-1003.

16. Giulia M, Battelli A, Bolognesi, Letizia Polito. Pathophysiology of circulating xanthine oxidoreductase: New emerging roles for a multi-tasking enzyme. Biochim Biophys Acta (BBA) 2014;1842:1502-17.

17. Godber BL, Schwarz G, Mendel RR, Lowe DJ, Bray RC, Eisenthal $\mathrm{R}$, et al. Molecular characterization of human xanthine oxidoreductase: the enzyme is grossly deficient in molybdenum and substantially deficient in iron-sulphur centers. Biochem J 2005;388:501-8.

18. Hae Young Chung, Bong Sook Baek, Sang Ho Song, Myoung Sook Kim, Jung Im Huh, Kyung Hee Shim, et al. Xanthine dehydrogenase/xanthine oxidase and oxidative stress. Age Omaha 1997;20:127-40.

19. Harrison R. Structure and function of xanthine oxidoreductase: where are we now? Free Radical Biol Med 2002;33:774-97.

20. Godber BL, Doel JJ, Sapkota GP, Blake DR, Stevens CR, Eisenthal $\mathrm{R}$, et al. Reduction of nitrite to nitric oxide catalyzed by xanthine oxidoreductase. J Biol Chem 2000;275:7757-63.

21. Godber BLJ, Doel JJ, Durgan J, Eisenthal R, Harrison R. A new route to peroxynitrite. A role for xanthine oxidoreductase. FEBS Lett 2000b;475:93-6.

22. Millar TM, Stevens CR, Benjamin N, Eisenthal R, Harrison R, Blake DR. Xanthine oxidoreductase catalyses the reduction of nitrates and nitrite to nitric acid under hypoxic conditions. FEBS Lett 1998;427:225-8.

23. Kurosaki M, Li M, Calzi, Scanziani E, Garattini E, Terao M. Tissue and cell-specific expression of mouse xanthine oxidoreductase gene in vivo: regulation by bacterial lipopolysaccharide. Biochem J 1995;306:225-34.

24. Saksela M, Apatite R, Raivio KO. Xanthine oxidoreductase gene expression and Enzyme activity in developing human tissues. Biol Neonate 1998;74:274-80.

25. Al-Khalidi UAS, Chaglassian TH. The species distribution of xanthine oxidase. Biochem J 1965;97:318-20.

26. Wang J, Van Praagh A, Hamilton E, Wang Q, Zou B, Muranjan M, et al. Serum xanthine oxidase: origin, regulation, and contribution to the control of trypanosome parasitemia. Antioxid Redox Signaling 2002;4:161-78.

27. Riario-Sforza G, Carcassi A, Bayeli PF, Marcolongo R, Marinello E, Montagnani M. Xanthine oxidase activity in the jejunal mucosa of patients with Gout. Boll Soc Ital Biol Sper 1969;45:785-6.

28. Auscher C, Amory N, Van der Kemp P, Delbarre F. Xanthine oxidase activity in human intestines: histochemical and radiochemical study. Adv Exp Med Biol 1979;122B:197-201.

29. Della Corte E, Gozzetti G, Novello F, Stirpe F. Properties of the xanthine oxidase from human liver. Biochim Biophys Acta 1969;191:164-6.

30. Guerciolini R, Szumlanski C, Weinshilboum RM. Human liver xanthine oxidase: nature and extent of individual variation. Clin Pharmacol Ther 1991;50:663-72.

31. Stirpe F, Ravaioli M, Battelli MG, Musiani S, Grazi GL. Xanthine oxidoreductase activity in human liver disease. Am J Gastroenterol 2002;97:2079-85.

32. Watts RW, Watts JE, Seegmiller JE. Xanthine oxidase activity in human tissues and its inhibition by allopurinol 4hydroxypyrazolo [3,4-d] pyrimidine. J Lab Clin Med 1965;66:688-97.

33. Sarnesto, Linder N, Raivio KO. Organ distribution and molecular forms of human xanthine dehydrogenase/xanthine oxidase protein. Lab Invest 1996; 7:48-56.

34. Bergmann F, Levene F, Tamir I, Rahat M. Oxidation of methyl derivatives of pteridin-4-one, lumazine and related pteridines by bovine milk xanthine oxidase. Biochim Biophys Acta 1977;480:21-38.

35. Rodkey FL, Ball EG. A rapid test for distinguishing human from cow's milk based upon a difference in their xanthine oxidase content. J Lab Clin Med 1946;3:354-6.

36. Krenitsky TA, Neil SM, Elion GB, Hitchings GH. A comparison of the specificities of xanthine oxidase and aldehyde oxidase. Arch Biochem Biophys 1972;150:585-99. 
37. Kooij M, Schijns WM, Frederiks CJF, Van Noorden J, James. Distribution of xanthine oxidoreductase activity in human tissues-a histochemical and biochemical study. Virchows Arch B Cell Pathol 1992;63:17-23.

38. Taibi G, Di Gaudio F, Nicotra CM. Xanthine dehydrogenase processes retinol to retinoic acid in human mammary epithelial cells. J Enzyme Inhib Med Chem 2008;23:317-27.

39. Pritsos CA. Cellular distribution, metabolism and regulation of the xanthine oxidoreductase enzyme system. Chem Biol Interact 2000;129:195-208.

40. Beedham C, John Wiley. Molybdenum hydroxylases In enzyme systems that metabolize drugs and other xenobiotics. Ioannides C 2002;147-87.

41. Meneshian A, Bulkley GB. The physiology of endothelial xanthine oxidase: from urate catabolism to reperfusion injury to inflammatory signal transduction. Microcirculation 2002; 9:161-75.

42. Ames BN, Cathcart R, Schwiers E, Hochstein P. Uric acid provides an antioxidant defense in humans against oxidant and radical-caused aging and cancer: a hypothesis. Proc Natl Acad Sci USA 1981;78:6858-62.

43. Berry CE, Hare JM. Xanthine oxidoreductase and cardiovascular disease: molecular mechanisms and pathophysiological implications. J Physiol 2004;555:589-606.

44. Peden DB. Uric acid is a major antioxidant in human nasal airway secretions. Proc Natl Acad Sci USA 1990;87:7638-42.

45. Kastenbauer S. Experimental meningitis in the rat: protection by uric acid at human physiological blood concentrations. Eur J Pharmacol 2001;425:149-52.

46. Becker BF. Uric acid as radical scavenger and antioxidant in the heart. Pflugers Arch 1989;415:127-35.

47. Becker BF. Towards the physiological function of uric acid. Free Radical Biol Med 1993;14:615-31.

48. Granger DN, Hollwarth ME, Parks DA. Ischemia-reperfusion injury: the role of oxygen-derived free radicals. Acta Physiol Scand 1986;548:47-63.

49. Finkel T. Signal transduction by reactive oxygen species in nonphagocytic cells. J Leukoc Biol 1999;65:337-40.

50. Fuh KC, Meneshian A, Patel CB, Takiar V, Bulkley GB. Signa transduction by reactive oxygen species: alternative paradigms for signaling specificity Surgery. 2002;131:601-12.

51. Garattini E, Mendel R, Romao MJ, Wright R, Terao $M$ Mammalian molybdo-flavoenzymes, an expanding family of proteins: structure, genetics, regulation, function and pathophysiology. Biochem J 2003;372:15-32.

52. Christen S. Marked elevation in cortical urate and xanthine oxidoreductase activity in experimental bacterial meningitis. Brain Res 2001;900:244-51.

53. Nagler RM. Characterization of the differentiated antioxidant profile of human saliva. Free Radical Biol Med 2002;32:268-77.

54. Kooij A, Schiller HJ, Schijns N, Van Noorden CJF, Frederiks WM. Conversion of xanthine dehydrogenase to xanthine oxidase in rat liver and plasma at the onset of reperfusion after ischemia. Hepatology 1994;19:1488-95.

55. Hannah M, Martin, John T, Hancock Vyv, Salisbury, Roger Harrison. Role of Xanthine oxidoreductase as an antimicrobial agent. Infect Immun 2004;72:4933-9.

56. Bulkley GB. Endothelial xanthine oxidase: a radical transducer of inflammatory signals for reticuloendothelial activation. $\mathrm{Br}$ J Surg 1993;80:686.

57. Bulkley GB. Reactive oxygen metabolites and reperfusion injury: aberrant triggering of reticuloendothelial function Lancet 1994:344:934-6.

58. Lipmann F, Owen CR. The antibacterial effect of enzymatic xanthine oxidation. Science 1943;98:246-8.

59. Keenan TW, S Patton. The structure of milk: implications for sampling and storage. A milk lipid globule membrane handbook of milk composition. In R G Jensen. ed. Academic Press; 1995. p. 5-50.

60. Adachi T, Fukushima T, Usami Y, K Hirano. Binding of human xanthine oxidase to sulphated glycosaminoglycans on the endothelial cell surface. Biochem J 1993;289:523-7.

61. Stevens CR, Millar TM, Clinch JG, Kanczler JM, Bodamyali T, Blake. Antibacterial properties of xanthine oxidase in human milk. Lancet 2000;356:829-30.
62. Rouquette M, Page S, Bryant R, Benboubetra M, Stevens CR, Blake DR, et al. Xanthine oxidoreductase is asymmetrically localized on the outer surface of human endothelial and epithelial cells in culture. FEBS Lett 1998;426:397-401.

63. Topham RW, Walker MC, Calisch MP. Liver xanthine dehydrogenase and iron mobilization. Biochem Biophys Res Commun 1982;109:1240-6.

64. Topham RW, Walker MC, Calisch MP, Williams RW. Evidence for the participation intestinal xanthine oxidase in the mucosal processing of iron. Biochem 1982;21:4529-35.

65. Stirpe F, Higgins T, Tazzari PL, Rozengurt E. Stimulation by xanthine oxidase of 3T3 Swiss fibroblasts and human lymphocytes. Exp Cell Res 1991;192:635-8.

66. Rao GN, Berk BC. Active oxygen species stimulate vascular smooth muscle cell growth and proto-oncogene expression. Circ Res 1992;70:593-9.

67. Galli A, Svegliati-Baroni G, Ceni E, Milani S, Ridolfi F, Salzano R, et al. Oxidative stress stimulates proliferation and invasiveness of hepatic stellate cells via a MMP2-mediated mechanism. Hepatology 2005;41:1074-84.

68. Mcmanaman JL, Palmer CA, Wright RM, Neville MC. Functional regulation of xanthine oxidoreductase expression and localization in the mouse mammary gland: evidence of a role in lipid secretion. J Physiol 2002;545:567-9.

69. Keenan TW. Milk lipid globules and their surrounding membrane: a brief history and perspectives for future research. J Mammary Gland Biol Neoplasia 2001;6:365-71.

70. Krenitsky TA, Spector T, Hall W. Xanthine oxidase from human liver: purification and characterization. Arch Biochem Biophys 1986;247:108-19.

71. Sanders SA, Eisenthal R, Harrison R. NADH oxidase activity of human xanthine oxidoreductase: generation of superoxide anion. Eur J Biochem 1997;245:541-8.

72. Harrison R. Human xanthine oxidoreductase: in search of a function. Biochem Soc Trans 1997;25:786-91.

73. Granger DN, Hollwarth ME, Parks DA. Ischemia-reperfusion injury: the role of oxygen-derived free radical. Acta Physiol Scand 1986;548:47-63.

74. Ledingham SI, Katayama O, Lachno DR, Yacoub M. Prolonged cardiac preservation Evaluation of the University of Wisconsin preservation solution by comparison with the St Thomas' Hospital cardioplegic solutions in the rat. Circulation 1990;82:IV351-IV358.

75. Martin HM. Cellular expression of xanthine oxidoreductase. PhD thesis, University of Bath; 2003.

76. Boueiz A, Damarla M, Hassoun PM. Xanthine oxidoreductase in respiratory and cardiovascular disorders. Am J Physiol Lung Cell Mol Physiol 2008;294:L830-L40.

77. Weinbroum A, Nielsen VG, Tan S, Gelman S, Matalon S, Skinner $\mathrm{KA}$, et al. Liver ischemia-reperfusion increases pulmonary permeability in the rat: the role of circulating xanthine oxidase. Am J Physiol Gastrointest Liver Physiol 1995;268:988-96.

78. Houston M, Estevez A, Chumley P, Aslan M, Marklund S, Parks DA, et al. Binding of xanthine oxidase to vascular endothelium kinetic characterization and oxidative impairment of nitric oxide-dependent signaling. J Biol Chem 1999;274:4985-94

79. Davies DF, Davies JR, Richards MA. Antibodies to reconstituted dried milk protein in coronary heart disease. J Atheroscl Res 1969;9:103-7.

80. Lewis WHP, Ng YLE. Human xanthine oxidase antibody levels: variation in males and females in Chinese and Europeans. Med Lab Sci 1991;48:84-8.

81. Kasper DL, Braunwald E, Fauci AS, Hauser SL, Longo DL, Jameson JL, et al. Princip Intern Med. New York: McGraw-Hill; 2008. p. 156.

82. Smalley RV, Guaspari A, Haase-Statz S, Anderson SA, Cederberg D, Hohneker JA. Allopurinol: intravenous use for prevention and treatment of hyperuricemia. J Clin Oncol 2000;1:1758-63.

83. Puig JG, Torres RJ, Mateos FA, Ramos TH, Arcas JM, Buño AS, et al. The spectrum of hypoxanthine-guanine phosphoribosyl transferase HPRT deficiency clinical experience based on 22 patients from 18 Spanish families. Med Balti 2001;80:102-12.

84. Stout JT, Caskey CT. Hprt: gene structure, expression, and mutation. Annu Rev Genet 1985;19:127-51. 
85. Roger Harrison. Physiological roles of xanthine oxidoreductase. Drug Metabol Rev 2004;36:363-75.

86. Robert Kmurray. Pyrimidine metabolism. 26 ed. Harpers illustrated Biochemistry; 2012. p. 300.

87. Hewinson J, Stevens CR, Millar TM. Vascular physiology and pathology of circulating xanthine oxidoreductase: from nucleotide sequence to functional enzyme. Redox Rep 2005;9:71-9.

88. Pacher P, Nivorozhkin A, Szabó C. Therapeutic effects of xanthine oxidase inhibitors: renaissance half a century after the discovery of allopurinol. Pharmacol Rev 2006;58:87-114.

89. Cejkova J, Vejrazka M, Platenık J, Stıpekb S. Age-related changes in superoxide dismutase, glutathione peroxidase, catalase, and xanthine oxidoreductase/xanthine oxidase activities in the rabbit cornea. Exp Gerontol 2004;39:1537-43.

90. Lin HC, Tsai SH, Chen CS, Chang YC, Lee CM, Lai ZY, et al. Structure-activity relationship of coumarin derivatives on xanthine oxidase inhibiting and free radical-scavenging activities. Biochem Pharmacol 2008;75:1416-25.

91. Okamoto K, Eger BT, Nishino To, Kondo S, Pai EF, Nishino TA. An extremely potent inhibitor of xanthine oxidoreductase crystal structure of the enzyme-inhibitor complex and mechanism of inhibition. J Biol Chem 2003; 278:1848-55.

92. Bruce SP. Febuxostat: a selective xanthine oxidase inhibitor for the treatment of hyperuricemia and gout. Ann Pharmacother 2006;40:2187-94.

93. Becker MA, Schumacher Jr HR, Wortmann RL, Macdonald PA, Eustace D, Palo WA, et al. Febuxostat compared with allopurinol in patients with hyperuricemia and gout. $\mathrm{N}$ Engl J Med 2005;353:2450-61.

94. Schumacher HR Jr. Febuxostat: a non-purine, selective inhibitor of xanthine oxidase for the management of hyperuricemia in patients with gout. Expert Opin Investig Drug 2005;14:893-903.

95. Kurtis Frank Sol. West, Milk thistle and hepatoprotection: A review of efficacy and safety. Available from: https:// examine come/supplements/milk-thistle/2011. [Last accessed on 04 Jun 2016].

96. Shivraj h nile, Cn khobragrde. Phytochemical analysis, antioxidant and xanthine oxidase inhibitory activity of Tephrosia purpurea linn. root extract. Indian J Nat Prod Resour 2010;2:52-8.

97. Kandhasamy Sowndhararajan, Jince Mary Joseph, Dharmar Rajendrakumaran. In vitro xanthine oxidase inhibitory activity of methanol extracts of Erythrina indica lam Leaves and stem bark. Asia Pacific J Trop Biomed 2012;s1415-s1417.

98. Uma maheswari $M$, Asokkumar K, Sivashanmugam AT, Remyaraju A, Subhadradevi V, Ravi TK. In vitro xanthine oxidase inhibitory activity of the fractions of Erythrina stricta roxb. J Ethnopharmacol 2009;124:646-8.

99. Tristan P Dew, Andrea J Day, Michael RA Morgan. Xanthine oxidase activity in vitro: effects of food extracts and components. J Agric Food Chem 2005;53:6510-5.

100. Http://wwwgoutpalcom/2728/gout-cures-natural-xanthineoxidase-inhibitors. [Last accessed on 04 Jun 2016].

101. Yasser Bustanji, Mohammad Hudaib, Khaled Tawaha, Mohammad K Mohammad, Ihab Almasri, Saja Hamed, Sawsan Oran. In vitro xanthine oxidase inhibition by selected jordanian medicinal plants. Jordan J Pharm Sci 2011;4:1.

102. Govindappa M, Sadananda TS, Channabasava R, Vinay B Raghavendra. In vitro anti-inflammatory, lipoxygenase, xanthine oxidase and acetylcholinesterase inhibitory activity of Tecoma stans 1 Juss Ex kunth. Int J Pharm Biol Sci 2011;2:275-85.

103. Subramanian L Jothy, Zakaria Zuraini, Sreenivasan, Sasidharan. Phytochemicals are screening, DPPH free radical scavenging and xanthine oxidase inhibitory activities of Cassia fistula seeds extract. J Med Plant Res 2011;5:1941-19.

104. Kong LD, Abliz Z, Zhou CX, Li LJ, Cheng CH, Tan RX. Glycosides and xanthine oxidase inhibitors from Conyza bonariensis. Phytochem 2001;58:645-51.

105. Chin-Hui Chen, Hsiu-Chen Chan, Yi-Tsu Chu, Hsin-Yi Ho, Pi-Yu Chen, Tzong-Huei Lee, et al. Antioxidant activity of some plant extracts towards xanthine oxidase, lipoxygenase, and Tyrosinase. Molecules 2009;14:2947-58.

106. Marie Bräunlich, Rune Slimestad, Helle Wangensteen, Cato Brede, Karl E Malterud. Extracts, anthocyanins and procyanidins from Aronia melanocarpa as radical scavengers and enzyme inhibitors. Nutrients 2013;5:663-78.

107. Li DQ, Zhao J, Li SP, Zhang QW. Discovery of xanthine oxidase inhibitors from a complex mixture using an online, restrictedaccess material coupled with column-switching liquid chromatography with a diode-array detection system. Anal Bioanal Chem 2014;406:1975-84.

108. Li D, Li S, Zhao J. Screening of xanthine oxidase inhibitors in complex mixtures using online HPLC coupled with post column fluorescence-based biochemical detection. J Sep Sci 2014;37:338-44.

109. Kong LD, Cai Y, Huang WW, Christopher HK, Cheng RX. Tan Inhibition of xanthine oxidase by some Chinese medicinal plants used to treat gout. J Ethnopharmacol 2000:73:199-207.

110. Boumerfeg S, Baghiani A, Djarmouni M. Inhibitory activity on xanthine oxidase and antioxidant properties of Teucrium polium L extracts. Chin Med 2012;3:30-41.

111. Tomonori U, Akio S, Takami K. Xanthine oxidase inhibitors from the leaves of Lagerstroemia speciosa L. Pers. Ethnopharmacol 2004;93:391-5.

112. Chiang HC, Lo YJ, Lu FJ. Xanthine oxidase inhibitors from the leaves of Alsophila spinulosa hook try on. J Enz Inhib 1994; 8:61-71.

113. Chen L, Wang W, Wang Y. Inhibitory effects of lithospermic acid on proliferation and migration of rat vascular smooth muscle cells. Acta Pharmacol Sin 2009;30:1245-52.

114. Jiao RH, Ge HM, Shi DH, Tan RX. An apigenin-derived xanthine oxidase inhibitor from palhinhaeacernua. J Nat Prod 2006;69:1089-91.

115. Wang SY, Yang CW, Liao JW, Zhen WW, Chu FH, Chang ST. Essential oil from leaves of Cinnamomum osmophloeum acts as a xanthine oxidase inhibitor and reduces the serum uric acid levels in oxonate-induced mice. Phytomedicine 2008;15:940-5.

116. Intisar Reehem Alsultanee, Mufeed Jalil Ewadh, Maha Fahdil Mohammed. Novel natural anti-gout medication extracts from Momdica charantia. J Nat Sci Res 2014;4:17.

117. Spanou C, Veskoukis AS, Kerasioti T, Kontou M, Angelis A. Flavonoid glycosides isolated from unique legume plant extracts as novel inhibitors of xanthine oxidase. Plos One 2012;7:3.

118. Nguyen MT, Awale S, Tezuka Y, Ueda J, Tran QL, Kadota S. Xanthine oxidase inhibitors from the flowers of Chrysanthemum sinense. Planta Med 2006;72:46-51.

119. Sevilay C, Levent C, Kadir TA. Inhibition of xanthine oxidase by Caulerpenynefrom caulerpaprolifera. Turk J Biochem 2012;37:445-51.

120. Yang CW, Tseng YH, Tsay HS, Kuo YH, Yang S. Lonicerahypoglauca inhibits xanthine oxidase and reduces serum uric acid in mice. Planta Med 2009:75:302-6.

121. Boumerfeg S, Baghiani AM, Amen D, Adjadj M, Belkhiri F. Inhibitory activity on xanthine oxidase and antioxidant properties of Teucrium polium. Chin Med 2012;3:30-41.

122. Nile SH, Khobragade CN. Phytochemical analysis, antioxidant and xanthine oxidase inhibitory activity of Tephrosia purpurea Linn root extract. Indian J Nat Prod Resour 2011;2:52-8.

123. Hudaib MM, Tawaha KA, Mohammad MK, Assaf AM, Issa AY, Alali $\mathrm{FQ}$, et al. Xanthine oxidase inhibitory activity of the methanolic extracts of selected Jordanian medicinal plants. Pharmacog Mag 2010;7:320-4.

124. Havlik J, Raquel Huebra GDL, Hejtmankova K, Fernandez Simonova J, Melich $\mathrm{M}$, et al. Xanthine oxidase inhibitory properties of czech medicinal plants. J Ethnopharmacol 2010;132:461-5.

125. Ványolós A, Gyapai 00, Támadi T, Hohmann J. Screening of hungarian mushrooms for xanthine oxidase inhibitory activity. Planta Med 2013;13:9.

126. Guerrero RO, Guzman AL. Inhibition of xanthine oxidase by puerto rican plant extracts. P R Health Sci J 1998;17:359-6.

127. Flemmig J, Kuchta K, Arnhold J, Rauwald HW. Olive leaf extract has xanthine oxidase inhibiting activity which confirms its traditional use for gout. Phytomedicine 2011;18:561-6. 
128. Kong LD, Cai Y, Huang WW, Cheng CH, Tan RX. Cinnamon cassia type Polygonum cuspidatum source of resvertrol demonstrated significant inhibition of xanthine oxidase indicating its potential for the treatment of gout. J Ethnopharmacol 2000;73:199-207.

129. Ling X, Bochu W. A review of phytotherapy of gout: the perspective of new pharmacological treatments. Pharmazie 2014;69:243-56.

130. Ajay Kumar, Wamik Azmi. Phytomedicine: a novel alternative for treatment of gout. Ann Phys Med 2014;3:80-8.

131. Rini Hendriani, Elian Yulinah Sukandar, Kusnandar Anggadiredja, Sukrasno. Invitro evaluation of xanthine oxidase inhibitory activity of selected medicinal plants. Int J Pharm Clin Res 2016;8:235-8.

132. Wahyuningsih, Elin Yulinah Sukandar, Sukrasno. In vitro xanthine oxidase inhibitor activity of ethanol extract and fraction roselle calyx (Hibiscus sabdariffa L.). Int J Pharm Clin Res 2016;8:619-22.

\section{How to cite this article}

- Uma Rajeswari Batchu, Kiranmai Mandava. Biochemical role of xanthine oxidoreductase and its natural inhibitors: an overview. Int J Pharm Pharm Sci 2016;8(10):57-65. 